\title{
Cleft palate-short stature-vertebral anomalies syndrome
}

INSERM

\section{Source}

INSERM. (1999). Orphanet: an online rare disease and orphan drug data base. Cleft palate-short stature-vertebral anomalies syndrome. ORPHA:2015

Cleft palate- short stature- vertebral anomalies is a multiple cong enital anomalies syndrome described in a father and son characterized by the association of cleft palate, peculiar facies (asymmetrical appearance, inner epicanthal folds, short nose, anteverted nostrils, low and back-oriented ears, thin upper lip and micrognathism), short stature, short neck, vertebral anomalies and intellectual disability. The transmission is presumed to be autosomal dominant. There have been no further descriptions in the literature since 1993. 